\title{
PELAKSANAAN PEMBELAJARAN MENULIS TEKS ULASAN SISWA KELAS VIII SMP NEGERI 17 KOTA BENGKULU
}

\author{
'Iksan Suryadi; ${ }^{2}$ Suhartono; ${ }^{3}$ Padi Utomo \\ ${ }^{1,2,3}$ Program Studi Pendidikan Bahasa Indonesia FKIP Universitas Bengkulu
}

Abstrak

\section{Korespondensi: ikhsansuryadi677@gmail.com}

Tujuan Penelitian ini untuk mendeskripsikan pelaksanaan pembelajaran menulis teks ulasan siswa kelas VIII SMP Negeri 17 Kota Bengkulu. Metode yang digunakan dalam penelitian ini adalah metode deskriptif kualitatif. Subjek dalam penelitian ini adalah guru dan siswa. Berdasarkan pelaksanaan pembelajaran menulis teks ulasan di kelas VIII SMP Negeri 17 Kota Bengkulu. Teknik pengumpulan data menggunakan observasi, wawancara, dan dokumentasi. Uji keabsahan data yang digunakan adalah triangulasi data. Hasil penelitian menunjukkan bahwa pelaksanaan pembelajaran menulis teks ulasan di kelas VIII menggunakan pendekatan saintifik sudah berdasarkan Rencana Pelaksanaan Pembelajaran yang telah dibuat oleh guru. Pelaksanaan pembelajaran yaitu guru memberikan petunjuk mengerjakan tugas menulis teks ulasan, siswa mengerjakan tugas menulis teks ulasan, siswa mengumpulkan tugas dan kemudian guru menilai teks ulasan dari siswa berdasarkan penilaian yang terdapat di dalam Rencana Pelaksanaan Pembelajaran yang di rancang oleh guru. Maka dari itu dapat disimpulkan bahwa sistematika pembelajaran yang baik salah satu penentu kualitas pembelajaran menulis teks ulasan yang dilakukan oleh siswa.

Kata Kunci: pelaksanaan, pembelajaran, menulis, teks ulasan

\section{Abstract}

The purpose of this research was to describe the implementation of learning to write review text of class VIII students of SMP Negeri 17 Bengkulu city. The method used in this research is a qualitative descriptive method. The subjects in this research were the teacher doing the implementation of learning and students were learning to write review text in class VIII of SMP Negeri 17 Bengkulu city. The technique of collecting the data used observation, interviews and documentation. The validity test of the data used is the data triangulation. The results of the research show that the implementation writing of review text learning in class VIII uses a scientific approach and the implemented based on the Learning Implementation Plan that has been made by the teacher. The teacher gives instructions to doing on the task of a review text writing, the student doing on the task of writing a review text, students collect assignments and then the teacher evaluates the review text from the students based on the assessment contained in the Learning Implementation Plan designed by the teacher.

Keyword: implementation of learning, write, review text 


\section{PENDAHULUAN}

Kurikulum dipakai pada sebuah lembaga pendidikan, dengan tujuan memperbaiki mutu dan kualitas pendidikan kurikulum sebelumnya, Perubahan kurikulum berdampak pada proses pembelajaran salah satunya terjadi pada proses pembelajaran bahasa Indonesia pada tingkat sekolah menengah pertama (SMP). Terjadinya perubahan kurikulum membuat siswa membutuhkan penyesuaian diri dengan sistem pembelajaran pada Kurikulum 2013 yaitu pembelajaran yang berbasis teks. Teks yang mengemban fungsi sosial dan tujuan tertentu untuk menjadi sumber aktualisasi diri dan mengembangkan kegiatan ilmiah atau saintifik. Mulai dari memberikan contoh dan menguraikan struktur serta satuan-satuan kebahasaan yang menjadi penanda keberadaan teks itu (pemodelan) hingga upaya siswa untuk menulis atau memproduksi sendiri teks yang diajarkan. Mahsun, (2014: 112).

Kurikulum yang berlaku di Indonesia ialah Kurikulum 2013. Oleh sebab itu, metode pengajaran bahasa Indonesia yang digunakan untuk mengajar SMP/MTs dan SMA/SMK/MA ialah metode saintifik. Langkah-langkah pembelajaran dalam metode tersebut terdiri dari kegiatan mengamati, menanya, mengeksplorasi atau mengumpulkan informasi, mengasosiasi, dan mengomunikasi.

SMP Negeri 17 Kota Bengkulu merupakan salah satu sekolah di Bengkulu yang menerapkan Kurikulum 2013. Sebagai sekolah yang menerapkan Kurikulum 2013, pembelajaran bahasa Indonesia di SMP Negeri 17 Kota Bengkulu menggunakan teks sebagai sarana pembelajarannya.

Salah satu teks yang diajarkan dalam pembelajaran Bahasa Indonesia adalah menulis teks ulasan. Teks ulasan adalah teks yang diajarkan di kelas VIII semester genap. Teks ulasan atau review text dalam pembelajaran bahasa Indonesia Kurikulum 2013 merupakan suatu teks yang mengulas film atau drama agar orang lain dapat memahami hasil penafsiran dan evaluasi penulisnya terhadap suatu film atau drama. Pembelajaran menulis teks ulasan ini dimaksudkan untuk membantu peserta didik memperoleh wawasan pengetahuan yang lebih luas agar terampil berpikir kritis dan kreatif serta mampu bertindak efektif menyelesaikan permasalahan dalam kehidupan nyata sebagaimana tercermin dalam teks.

Secara umum, pembelajaran menulis di sekolah masih kurang diminati siswa. Karena menulis dianggap kegiatan yang sulit pada pembelajaran, kesulitan terletak pada pengembangan ide dan penggunaan bahasa, serta struktur yang tepat pada saat menulis, dalam kondisi ini, guru perlu mengoptimalkan penggunaan strategi pembelajaran yang menarik dan inovatif.

Rumusan masalah yang terdapat pada penelitian ini adalah Bagaimana Perencanaan Pembelajaran menulis teks ulasan siswa kelas VIII SMP Negeri 17 Kota Bengkulu dan Bagaimana Pelaksanaan Pembelajaran Menulis Teks Ulasan Siswa Kelas VIII SMP Negeri 17 Kota Bengkulu.

Tujuan penelitian ini adalah Mendeskripsikan perencanaan pembelajaran menulis teks ulasan siswa Kelas VIII SMP Negeri 17 Kota Bengkulu. Dan mendeskripsikan pelaksanaan pembelajaran menulis teks ulasan siswa Kelas VIII SMP Negeri 17 Kota Bengkulu. Manfaat Penelitian dari Hasil penelitian ini dapat memberikan manfaat secara teoritis maupun praktis.

Manfaat Teoritis penelitian diharapkan dapat memberi pandangan baru serta menjadi bahan pengembangan dalam kegiatan pembelajaran menulis teks ulasan. Manfaat 
Praktis Bagi guru Penelitian ini diharapkan dapat menjadi bahan pertimbangan dalam pembelajaran teks ulasan sehingga dapat memperoleh hasil yang maksimal. Bagi sekolah Hasil penelitian diharapkan dapat menjadi dokumentasi bagi sekolah terkait dengan pelaksanaan pembelajaran teks ulasan.

Penelitian ini mencoba mengungkapkan bagaimana pelaksanaan pembelajaran menulis teks ulasan yang diajarkan di SMP Negeri 17 Kota Bengkulu berdasarkan kurikulum 2013, apakah sudah sesuai dengan prosedur kurikulum 2013 dan tahap apa saja yang guru lakukan di dalam pelaksanaan pembelajaran menulis teks ulasan serta strategi apa saja yang guru gunakan untuk mencapai tujuan pembelajaran teks ulasan. Berdasarkan pemaparan di atas, menjadi landasan peneliti untuk meneliti dan mendeskripsikan proses pelaksanaan pembelajaran menulis teks ulasan kelas VIII oleh guru di SMP Negeri 17 Kota Bengkulu berdasarkan kurikulum 2013.

Pengertian Pembelajaran, Pembelajaran adalah suatu kegiatan yang mengandung terjadinya proses penguasaan pengetahuan, keterampilan dan sikap oleh subjek yang sedang belajar. Pelaksanaan pembelajaran akan berjalan efektif apabila didahului dengan penyiapan rencana pelaksanaan pembelajaran (RPP) yang dikembangkan oleh guru baik secara individual maupun kelompok yang mengacu pada silabus. (Daryanto, 2014: 1)

Komponen Pembelajaran Rusman (2013: 119) menyatakan bahwa di dalam pembelajaran terdapat komponen-komponen, masing-masing membentuk integritas atau satu kesatuan yang utuh diantaranya yaitu sebagai berikut : Tujuan Pembelajaran Tujuan pembelajaran umum seperti: standar kompetensi dan kompetensi dasar. Sedangkan tujuan pembelajaran khusus, yaitu berupa indikator pembelajaran. Tujuan pembelajaran ini dimaksudkan untuk meningkatkan kemampuan, kecerdasan, pengetahuan, kepribadian, akhlak mulia serta keterampilan untuk hidup mandiri dan mengikuti pendidikan ke jenjang yang lebih tinggi.

Sumber belajar bisa dalam bentuk buku, lingkungan, surat kabar, digital konten, dan sumber informasi lainya. Strategi Pembelajaran Suatu cara yang digunakan guru untuk menyampaikan informasi atau materi pelajaran, dan kegiatan yang mendukung penyelesaian tujuan pembelajaran. Strategi pembelajaran pada hakikatnya merupakan prinsip-prinsip psikologi dan prinsip-prinsip pendidikan bagi perkembangan siswa. Media Pembelajaran Yaitu berupa sofware dan hardware untuk membantu proses interaksi guru dengan siswa dan interaksi siswa dengan lingkungan belajar dan sebagai alat bantu bagi guru untuk menunjang penggunaan metode pembelajaran yang digunakan oleh guru.. Kata media berasal dari bahasa latin dan merupakan bentuk jamak dari kata medium yang secara harfiah berarti perantara atau pengantar pesan dari pengirim ke penerima (Arif, 2010: 6).

Evaluasi pembelajaran merupakan alat indikator untuk menilai pencapaian tujuan-tujuan yang telah ditentukan serta menilai proses pelaksanaan pembelajaran secara keseluruhan. Evaluasi bukan hanya sekedar menilai suatu aktivitas secara spontan dan insidental, melainkan merupakan kegiatan untuk menilai sesuatu secara terencana, sistematik, dan terarah berdasarkan tujuan yang jelas dan Komponen pembelajaran adalah penentu dari keberhasilan proses pembelajaran.

Berkaitan dengan pendekatan saintifik, Daryanto (2014:51-52) menyatakan pembelajaran dengan pendekatan saintifik adalah proses pembelajaran yang dirancang sedemikian rupa agar peserta didik secara aktif mengonstruksikan konsep, hukum atau prinsip melalui tahapan-tahapan mengamati (untuk mengidentifikasi atau menemukan 
masalah), merumuskan masalah, mengajukan atau merumuskan hipotesis, mengumpulkan data dan berbagi teknik, menganalisis data, menarik kesimpulan.

Ketika kita mengekspresikan gagasan secara lisan (berbicara) atau secara tulis (menulis) berarti kita telah menciptakan teks. Ketika menyimak atau membaca, pada dasarnya kita telah menginterpretasikan makna teks. Dari fakta tersebut, dapat disimpulkan bahwa teks adalah ujaran (lisan) atau tulis bermakna yang berfungsi untuk mengekspresikan gagasan (Mahsun, 2014: 112)

Dalam menulis teks ulasan juga terdapat ciri-cirinya yang menjadikan teks ulasan berbeda dengan teks-teks lainya. Yustina, (2017: 3) menjelaskan bahwa ada 3 ciri-ciri teks ulasan ialah sebagai berikut:

1. Teks ulasan memuat informasi berdasarkan pandangan atau opini penulis terhadap karya.

2. Pendapat atau opini yang ditulis berupa fakta yang di interpretasikan dari karya tersebut.

3. Teks ulasan yang mengulas buku/novel/karya tulis lainya dikenal sebagai istilah resensi.

Struktur teks ulasan adalah bagian-bagian yang membangun sebuah teks ulasan sehingga menjadi suatu teks ulasan yang utuh. Menurut Yustina (2017: 10) teks ulasan memiliki struktur teks sebagai berikut :

1. Identitas karya, berisi identitas yang diulas baik berupa buku maupun film atau drama.

2. Orientasi, berisi pengenalan tentang gambaran umum sebuah karya yang akan di ulas.

3. Sinopsis, berisi ringkasan yang menggambarkan pemahaman penulis ulasan terhadap isi karya yang diulas.

4. Analisis berisi paparan tentang keberadaan unsur-unsur yang diulas, seperti unsur intrinsik dan ekstrinsik pada karya sastra.

5. Evaluasi, berisi paparan kelebihan dan kekurangan suatu karya yang diulas.

6. Rekomendasi, berisi ajakan untuk membaca buku atau menonton film yang diulas beserta manfaat yang akan didapatkan.

\section{METODE}

Metode pada penelitian ini adalah metode deskriptif dengan pendekatan kualitatif. Data dalam penelitian ini adalah berupa Pelaksanaan pembelajaran menulis teks ulasan siswa kelas VII SMP Negeri 17 Kota Bengkulu. Seperti kegiatan pendahuluan pembelajaran, kegiatan inti, dan penutup. Di buat dalam bentuk lembar observasi pembelajaran dan lembar wawancara oleh guru terhadap pelaksanaan pembelajaran yang dilaksanakan .

Sumber data dalam penelitian ini adalah Guru Bahasa Indonesia SMP Negeri 17 Kota Bengkulu. Teknik pengumpulan data yang digunakan dalam penelitian ini adalah teknik observasi, wawancara, dokumentasi. Instrumen penelitian dalam penelitian ini adalah berupa pedoman observasi, pedoman wawancara dan foto-foto kegiatan pembelajaran.

Teknik analisis data pada penelitian ini ialah reduksi data merujuk pada pemilihan, pemfokusan, penyederhanaan, abstraksi, dan transformasian "data mentah" yang terjadi dalam catatan lapangan tertulis. Display data kumpulan informasi yang tersusun yang membolehkan pendeskripsian menyistematiskan data agar lebih utuh. Penarikan/ verifikasi kesimpulan seluruh data dan disimpulkan. 


\section{HASIL DAN PEMBAHASAN}

\section{Hasil}

Hasil penelitian merupakan uraian atau deskripsi dari data yang telah diperoleh selama masa penelitian. Hasil penelitian pelaksanaan pembelajaran menulis teks ulasan kelas VIII SMP Negeri 17 Kota Bengkulu diperoleh melalui observasi, wawancara, dan dokumentasi. Observasi dilakukan dengan melihat langsung pelaksanaan pembelajaran di kelas. Wawancara dilakukan dengan salah satu guru mata pelajaran Bahasa Indonesia kelas VIII. Dokumentasi penelitian berupa, RPP, serta foto-foto kegiatan siswa selama proses pembelajaran. Sementara itu, RPP yang digunakan selama proses pembelajaran dibuat oleh guru. RPP digunakan untuk 4 kali pertemuan. Sesuai dengan komponen yang terdapat pada silabus, antara lain: Kompetensi Inti, Kompetensi dasar (KD), tujuan pembelajaran, materi pokok pembelajaran, metode pembelajaran, media pembelajaran dan evaluasi pembelajaran, Serta alokasi waktu, dan sumber belajar. Kompetensi Dasar (KD) yang terdapat dalam silabus, yaitu KD 3.11, 4.11, 3.12, 4.12 Materi pokok secara umum terdiri dari pengertian teks ulasan, macam-macam/ ciri-ciri teks ulasan, kelebihan dan kekurangan teks ulasan, struktur teks ulasan, unsur kebahasaan teks ulasan dan menulis teks ulasan.

Penelitian ini mendeskripsikan pelaksanaan pembelajaran menulis teks ulasan siswa kelas VIII SMP Negeri 17 Kota Bengkulu. Berdasarkan hasil penelitian tentang pelaksanaan pembelajaran menulis teks ulasan hasil dan pembahasan ditemukan sebagai berikut.

Dari penelitian ditemukan bahwa, Pelaksanaan pembelajaran dilakukan dengan tiga komponen yaitu kegiatan pendahuluan, kegiatan inti, dan penutup.

1. Kegiatan Pendahuluan

Pada kegiatan pendahuluan, guru menyiapkan peserta didik secara psikis dan fisik untuk mengikuti proses pembelajaran, guru melaksanakan apersepsi dengan mengaitkan materi sebelumnya dengan materi yang akan diajarkan, guru menjelaskan tujuan pembelajaran atau kompetensi dasar yang akan dicapai hal tersebut dilaksanakan guru bertujuan untuk siswa dapat mengikuti pembelajaran yang akan dilaksanakan, dengan adanya pendahuluan, maka pembelajaran akan siap di dimulai atau dilaksanakan berdasarkan tahapan Kurikulum 2013 (Rusman, 2013: 11) .

Seperti pada kutipan berikut: Menyiapkan peserta didik secara psikis dan fisik untuk mengikuti proses pembelajaran.

$\mathrm{G}(1)$ : "Selamat pagi anak-anak".

$\mathrm{S}(2)$ : "Pagi Buk".

G(3) : "Bagaimana kabarnya, sehat semua"?

S(4) : "Alhamdulillah sehat Buk"

G(5) : "Iya anak-anak syukurlah, karena kalian harus menjaga kesehatan agar selalu semangat dalam belajar", semangat kan?

$\mathrm{S}(6)$ : "Iya Buk, semangat"

$G(7)$ : "silahkan duduk tempatnya masing-masing nak"

$\mathrm{S}(8)$ : "Baik Buk"

G(9) : Nah, pada ketua kelas silahkan untuk memimpin doa. 
Apersepsi atau penilaian kemampuan awal yang dimiliki siswa, guru menghubungkan materi pelajaran yang telah dimiliki siswa dengan materi pelajari sebelumnya pada dialog sebagai berikut :

G(10) : "Anak-anak sekalian, pertemuan sebelumnya kita telah belajar tentang teks eksplanasi, apa itu teks ekplanasi ada yang masih ingat?

S(11) : "Masih Buk"

$\mathrm{G}(12)$ : "Apa itu teks eksplanasi?

S(13) : "Berisikan tentang informasi tentang suatu peristiwa Buk"

G(14) : "Iya benar, pelajaran pertemuan kali ini berkaitan dengan pembahasan sebelumnya, materi pembelajaran kali ini yaitu teks ulasan, yang mana nantinya kalian dapat mengulas suatu hal"

G(15) : 'Dan coba kalian bayangkan dari membaca cerpen, atau novel bisa membuat karya tulis berupa ulasan, dan dari menonton bisa menjadi tulisan, bukankah itu menarik anak-anak?

S(16) : "Iya Buk"

Menjelaskan tujuan pembelajaran atau kompetensi dasar yang akan dicapai :

G(17) : "Nah, Pada pertemuan pertama ini, ibu ingin menyampaikan tujuan pembelajaran kita, yaitu kita akan belajar mengenai teks ulasan".

$\mathrm{S}(18)$ : "Iya Buk"

G(19) : “Pembelajaran kali ini yaitu KD 3.11 tentang mengidentifikasi informasi pada teks ulasan, nanti kalian belajar tentang pengertian teks ulasan dan macam-macam teks ulasan"

2. Kegiatan Inti

Kegiatan inti pembelajaran guru meminta siswa untuk memahami pengertian teks ulasan dan ciri-ciri teks ulasan, sesuai dengan KD 3.11 mengidentifikasi informasi pada teks ulasan, guru membentuk kelompok yang terdiri 4-5 orang siswa, kemudian, guru meminta peserta didik membuka buku bahasa Indonesia tentang teks ulasan serta meminta siswa untuk menganalisis pengertian teks eksposisi, memahami ciri-ciri teks ulasan dan Setelah waktu berdiskusi selesai guru meminta siswa untuk mempresentasikan hasil kerja mereka kepada kelompok lain. Hal ini berhubungan dengan model pembelajaran Kurikulum 2013 yang berbasis saintifik, model pembelajaran ini memiliki lima tahapan yaitu mengamati, menanya, menalar, mencoba dan mengomunikasikan. Pada pembelajaran yang dilaksanakan oleh siswa, siswa telah menerapkan beberapa langkah seperti mengamati, menanya dan mengomunikasikan. Di akhir pertemuan guru memberikan refleksi kepada siswa guna memberikan siswa penguatan mengenai materi yang telah dipelajari pada pertemuan pertama ini.

Seperti dalam kutipan dialog sebagai berikut :

G(24) : "Anak-anak sekalian, sebelum Ibu menyampaikan materi, silahkan buka buku cetak kalian, halaman 4-5, lalu baca teks ulasan yang berjudul "Hujan karya Tereliye" dan teks ulasan "Sisi Lain Raden Ajeng Kartini”".

S(25) : "Baik Buk".

G(26) : "Dan jangan lupa baca serta maknai cerita tersebut". 
Pada pembelajaran ini, siswa melakukan tahap mengeksplor (mengumpulkan informasi) yaitu dengan membaca sendiri buku terlebih dahulu dan mengasosiasi hal ini berguna untuk pemahaman awal siswa, lalu mencari informasi seluas-luasnya (mengolah informasi) dengan memaknai isi teks atau cerita yang ada dibuku dengan begitu siswa dapat mengerti isi dan maksud dari cerita yang dibaca. Setelah siswa di suruh membaca dan memaknai teks ulasan, guru menjelaskan materi mengenai pengertian teks ulasan dan ciri-ciri dan aspek-aspek di dalam teks ulasan, seperti identitas buku, sinopsis, nilai buku, dan keterbacaan atau kecocokan pembacanya, Selain itu guru menjelaskan tentang ciri-ciri teks ulasan berupa teks ulasan memuat informasi berdasarkan pandangan opini penulis terhadap suatu karya, pendapat atau opini ditulis berupa fakta yang diinterpretasikan dari karya tersebut, teks ulasan yang mengulas buku/novel/karya tulis lainya dikenal dengan istilah resensi, tahapan kegiatan inti tersebut berhubungan dengan komponen tahapan kegiatan inti di kurikulum 2013 dengan demikian guru telah melaksanakan prosedur kegiatan inti yang mengarah pada kurikulum 2013.

G(27) : "Bagaimana, setelah membaca tadi, apa yang kalian dapatkan anakanak"?

S(28) : "Ada teks "Hujan karya Tereliye dan teks Sisi Lain Raden Ajeng Kartini Buk"

G(29) : "Iya benar, kalian bisa mengetahui tentang mereka setelah membaca tadi, dan sekarang ibu akan menjelaskan apa itu pengertian teks ulasan dan aspek di dalam teks ulasan, teks ulasan yaitu teks yang mengulas suatu karya berupa tulisan hingga film, dalam teks ulasan terdapat seperti identitas buku, sinopsis, nilai buku, dan keterbacaan atau kecocokan pembacanya"

S(30) : Merespon dengan menganggukkan kepala

G(31) : Jadi teks ulasan adalah teks yang mengulas karya, bisa berupa novel, cerpen hingga film, jadi dengan membaca atau melihat karya tersebut nanti anak-anak bisa mengulasnya, atau menuliskan di buku, paham anak-anak?

S(32) : "Iya buk "Setelah penjelasan tentang pengertian aspek teks ulasan guru membentuk siswa dalam kelompok, 1 kelompok terdiri atas 45 orang seperti dalam kutipan dialog berikut :

G(33) : "Mohon perhatiannya anak-anak, silahkan bentuk kelompok 4-5 orang dalam 1 kelompoknya, agar kalian bisa berdiskusi antar teman nantinya"

S(34) : "Baik Buk."

G(35) : "Bentuk kelompok kalian berdasarkan bangku terdekat agar tidak berantakan ya nak"

S(36) : "Iya buk"

G(37) : "Lalu kerjakan pada Buku halaman 6 yang Uji Kompetensi 1 yaitu mencari judul-judul yang kalian ketahui berkaitan dengan jenis-jenis karya, seperti cerpen, novel, film dan sebagainya kemudian tulislah isinya secara singkat berdasarkan yang telah ibu jelaskan tadi nak"

S(38) : "Baik Buk" 
Pertemuan kedua masih membahas mengenai KD 4.11 dengan materi pembelajaran menceritakan kembali isi teks ulasan. Sebelum masuk ke dalam materi pada pertemuan kedua ini. Guru terlebih dahulu mengulas kembali materi pada pertemuan sebelumnya guna menyegarkan kembali ingatan siswa, karena akan berhubungan dengan materi yang akan dipelajari oleh siswa. Pada pendahuluan kegiatan pembelajaran guru melaksanakan apersepsi kepada siswa dengan memberikan beberapa pertanyaan yang memancing siswa untuk aktif dalam kegiatan pembelajaran.

Setelah itu, guru meminta siswa untuk membentuk kelompok yang terdiri 45 orang siswa. Untuk mengerjakan soal KD 4.11 dengan materi "Petjah" pada pertemuan kedua ini yaitu penjelasan kembali teks ulasan dan mengungkapkan kelebihan dan kekurangan teks ulasan. Setelah semua kelompok menyelesaikan diskusinya, guru meminta siswa untuk mempresentasikan hasil kerja mereka. Pada akhir pertemuan guru memberikan refleksi mengenai materi yang baru saja dipelajari dan memberikan gambaran materi yang akan dipelajari pada pertemuan selanjutnya.

Pertemuan ketiga membahas KD 3.12 dengan materi teks ulasan "Cek Tokoh Sebelah dan Resensi Petjah". Yaitu menelaah struktur teks ulasan dan kaidah kebahasaan teks ulasan, guru mengawali kegiatan inti dengan melaksanakan apersepsi memancing pengetahuan di pertemuan sebelumnya, kemudian membentuk siswa secara berkelompok 4-5 orang siswa tiap kelompoknya untuk mengerjakan struktur teks ulasan "Resensi Petjah" dan setelah di kerjakan siswa di beri arahan untuk menjelaskan hasil kerjanya di depan kelas dan melaksanakan tanya jawab antar teman dan guru memberikan arahan atau penjelasan lengkapnya.

Pertemuan Keempat yaitu KD 4.12 dengan materi pelajaran yaitu "Film Pensil Patah" pada pertemuan ini siswa menyusun teks ulasan berdasarkan langkahlangkah penyusunan teks ulasan, serta menyajikan tanggapan berupa teks ulasan berdasarkan film yang di saksikan dengan memperhatikan struktur, kaidah kebahasaan, kekurangan dan kelebihan dan aspek lainya, pada pertemuan kali ini guru menjelaskan bahwa hari ini akan diadakan kegiatan menulis teks ulasan dengan menggunakan media film "Pensil Patah", kemudian guru menjelaskan langkahlangkah menulis teks ulasan serta alat apa saja yang akan disiapkan saat menulis teks ulasan dengan media film yang akan di tonton, lalu guru mempersiapkan siswa duduk secara rapi dan memulai tayangan filmnya, setelah selesai siswa di suruh mengerjakan teks ulasan berdasarkan film yang di tonton berdasarkan struktur, kaidah kebahasaan, langkah menulis dan lain sebagainya.

3. Kegiatan Penutup

Pada akhir pembelajaran peserta didik bersama guru menyimpulkan pembelajaran. Bersama guru, peserta didik mengidentifikasi hambatan-hambatan yang dialami saat memahami struktur teks ulasan guru membantu siswa untuk melakukan refleksi atau evaluasi terhadap penyelidikan mereka dan proses-proses yang mereka gunakan.

Evaluasi kelas dilakukan dengan melakukan penilaian kompetensi keterampilan, pengetahuan dan penilaian kompetensi sikap Evaluasi pembelajaran bahasa Indonesia berdasarkan Kurikulum 2013, guru melakukan evaluasi otentik 
dengan penilaian kompetensi keterampilan, penilaian kompetensi pengetahuan dan penilaian kompetensi sikap. Penilaian kompetensi pengetahuan terinci dengan dilakukannya penilaian unjuk kerja, penilaian kompetensi keterampilan terinci dengan dilakukannya penilaian kerja siswa. Penilaian keterampilan untuk mengetahui seberapa paham siswa dengan melihat hasil kerja mereka berupa tulisan menulis teks ulasan. Penilaian sikap berkaitan dengan nilai atau norma yang berhubungan dengan suatu kegiatan pembelajaran dan sikap berhubungan dengan kompetensi afektif lintas kurikulum yang relevan dengan mata pelajaran. Penilaian-penilaian ini cocok digunakan untuk menilai ketercapaian kompetensi yang menuntut peserta didik melakukan tugas tertentu dalam Kurikulum 2013.

Seperti dalam Kutipan sebagai berikut:

Guru melaksanakan kegiatan penutup di setiap pembelajarannya berdasarkan kurikulum 2013 yang mana tahapan tersebut sudah dilaksanakan oleh guru yaitu kegiatan penutup dilaksanakan dengan bersama-sama peserta didik atau sendiri membuat rangkuman/simpulan pelajaran, melakukan refleksi terhadap kegiatan sudah dilaksanakan ,memberikan umpan balik terhadap proses pembelajaran, merencanakan tindak lanjut seperti pemberian tugas berikutnya atau arahan pembelajaran berikutnya, guru juga memberi apresiasi kepada siswa terlebih dahulu, seperti memberikan tepuk tangan karena telah menyelesaikan tugas yang telah di berikan guru, hal tersebut dibuktikan dalam kutipan-kutipan dialog sebagai berikut: Merefleksi

G(85) : "Dari hasil kerja kalian pada pertemuan pertama ini, sudah baik dan boleh tepuk tangan untuk kalian semua".

$S(86):$ (Seluruh siswa bertepuk tangan)

$\mathrm{G}(87)$ : "Setelah pembelajaran hari ini, apa yang kalian dapatkan?".

$\mathrm{S}(88)$ : "Mengetahui pengertian teks ulasan Bu.

G(89) : "Selain pengertian apa lagi yang kalian bisa dapatkan pada pembelajaran kali ini?".

S(90) : Ciri-ciri teks ulasan Buk".

G(91) : "Ya benar sekali, maka bisa kita simpulkan bahwa pengertian teks ulasan ialah mengulas suatu karya , dan ciri-ciri teks ulasan ialah yang memuat informasi berdasarkan pendapat, pendapat yang ditulis berupa fakta, teks ulasan mengulas buku, novel hingga karya lainya seperti film, bagaimana sudah bisa dipahami anak-anak?

G(92) : "Iya Buk"

G(93) : "Pada hari, ini ibu akhiri pembelajaran kita, dari pembelajaran hari ini kita sudah tau apa itu teks ulasan dan ciri-cirinya. Untuk dirumah silahkan baca buku halaman 6-9 untuk bahan bacaan pertemuan berikutnya, Kepada ketua kelas silahkan pimpin doa". Setelah guru merefleksi pembelajaran, dan menanyakan kepada siswa apa saja yang telah di ketahui atau di dapatkan pada pertemuan pertama, lalu guru mempersilahkan ketua kelas untuk memimpin doa, Ketua kelas memimpin hormat dan siswa mengucapkan "Asalamuualikum warohamtulillah hiwabarokatub". 


\section{Pembahasan}

Setelah data yang diperoleh dari hasil penelitian, direduksi dan disajikan, berikut ini dilakukan pembahasan terhadap hasil penelitian tersebut. Bagian ini membahas tentang perencanaan, pelaksanaan, dan evaluasi pembelajaran.

Hasil penelitian didapati Perancangan Pelaksanaan pembelajaran yang di buat oleh guru di dasarkan dari kurikulum 2013, dan Pembelajaran yang laksanakan di SMP Negeri 17 Kota Bengkulu dikembangkan dengan memperhatikan KI dan KD yang di sesuaikan oleh tujuan pembelajaran, dan capaian dari pembelajaran. Berdasarkan pengamatan, rencana pelaksanaan pembelajaran (RPP) menulis teks ulasan yang di buat guru berdasarkan kurikulum 2013, bahwa perancangan pembelajaran yang di buat guru sudah bagus, dikarenakan sudah melengkapi komponen seperti (1) Tujuan Pembelajaran, (2) Materi Pembelajaran, (3) Metode Pembelajaran, (4) Media Pembelajaran, serta alokasi waktu pembelajaran. Sesuai dengan Rusman (2013: 119) Menyatakan bahwa di dalam pembelajaran terdapat komponen-komponen, masing-masing membentuk integritas atau satu kesatuan yang utuh.

\section{PENUTUP}

Dari penelitian ditemukan bahwa, Pelaksanaan pembelajaran dilakukan dengan tiga komponen yaitu kegiatan pendahuluan, kegiatan inti, dan penutup.

1. Pendahuluan

Pada kegiatan pendahuluan, guru menyiapkan peserta didik secara psikis dan fisik untuk mengikuti proses pembelajaran, guru melaksanakan apersepsi dengan mengaitkan materi sebelumnya dengan materi yang akan diajarkan, guru menjelaskan tujuan pembelajaran atau kompetensi dasar yang akan dicapai hal tersebut dilaksanakan guru bertujuan untuk siswa dapat mengikuti pembelajaran yang akan dilaksanakan, dengan adanya pendahuluan, maka pembelajaran akan siap di dimulai atau dilaksanakan berdasarkan tahapan kurikulum 2013 Rusman (2013: 11) .

2. Kegiatan Inti

Kegiatan inti merupakan kegiatan pembentukan kompetensi siswa, didasari pembelajaran kurikulum 2013 pembelajaran akan efektif jika peserta didik terlibat secara aktif, baik mental, fisik, maupun sosialnya. Berdasarkan hasil pengamatan dalam pelaksanaan pembelajaran menulis teks ulasan di kelas VIII SMP Negeri 17 Kota Bengkulu. Guru terlihat cukup menguasai materi pembelajaran, hal ini di temui pada saat penelitian, guru menjelaskan tahap demi-tahap materi-materi yang di ajarkan berdasarkan pemahaman guru serta improvisasi di dalam tiap penjelasannya, namun tak jarang pula guru melihat buku pegangan guru pada setiap pembelajaran, untuk dijadikan bahan ingatan, atau bacaan sekilas oleh guru. dan menghubungkan dengan hal lain yang masih relevan akan tetapi kenyataannya guru lebih dominan menggunakan teknik ceramah sehingga guru lebih mendominasi dalam kegiatan belajar-mengajar.

3. Penutup

Guru bersama-sama dengan siswa menyimpulkan pembelajaran, merefleksi terhadap proses dan hasil pembelajaran, memberikan umpan balik, serta menyampaikan rencana pembelajaran pada pertemuan berikutnya. 
Berdasarkan pengamatan materi yang digunakan guru selama proses pembelajaran sudah sesuai dengan Kurikulum K13 pada KD dan tujuan pembelajaran dalam RPP yang terdiri dari pengertian teks ulasan, ciri-ciri teks ulasan, struktur teks ulasan, unsur kebahasaan teks ulasan, serta langkah-langkah di dalam menulis teks ulasan dan menulis teks ulasan.

Berdasarkan kesimpulan di atas terkait pelaksanaan pembelajaran teks ulasan kelas VIII SMP Negeri 17 Kota Bengkulu terdapat beberapa saran yang dapat di sampaikan , yaitu sebagai berikut.

1. Bagi guru

Guru sudah mengajar dengan sangat baik, namun sebaiknya pada proses pembelajaran materi yang digunakan diperbanyak seperti contoh-contoh teks di dalam pembelajaran.

2. Bagi siswa

Selama proses pembelajaran, siswa sudah menunjukkan keseriusan dalam mengikuti pembelajaran, namun terkadang terlihat sebagian siswa tampak jenuh dan bosan dalam mengikuti pembelajaran. Sebaiknya, siswa lebih bersemangat untuk mengikuti pembelajaran bahasa Indonesia.

3. Bagi sekolah

Fasilitas sekolah yang disediakan untuk proses pembelajaran sudah lengkap dan baik. Namun, pihak sekolah perlu memperhatikan perawatan fasilitas yang ada. Dikarenakan masih terdapatnya fasilitas sekolah yang fungsinya tidak optimal akibat dari perawatan yang kurang.

\section{DAFTAR PUSTAKA}

Arif, R. (2010). Media Pendidikan. Jakarta: Rajawali Pers.

Daryanto. (2014). Pendekatan Pembelajaran Saintifik. Yogyakarta: Penerbit Gava Media.

Mahsun. (2014). Teks Pembelajaran Bahasa Indonesia Kurikulum 2013. Jakarta: Rajawali Pers.

Rusman. (2013). Belajar dan Pembelajaran Berbasis Komputer. Bandung: Alfabeta.

Yustina, (2017). Bahasa Indonesia. Surabaya: Intan Pariwara. 